\title{
Gut clearance rate as predictor of food limitation situations. Application to two estuarine copepods: Acartia bifilosa and Eurytemora affinis
}

\author{
Xabier Irigoien *, Jacques Castel ${ }^{* *}$, Stéphane Gasparini \\ Laboratoire d'Océanographie Biologique, Université Bordeaux I, F-33120 Arcachon, France
}

\begin{abstract}
Gut clearance rate-temperature relationships were determined in laboratory conditions, with tood in excess, and in the field to assess possible food limitation situations for 2 estuarine copepods, Eurytemora affinis and Acartia bifilosa. From the comparison of these relationships, it appeared that $A$. bifilosa was food limited whereas $E$. affinis was not. The gut clearance rate-temperature regressions obtained with nonsaturating food were not significantly different from the one obtained by Dam \& Peterson (J exp mar Biol Ecol 123:1-14, 1988) for several copepod species. Consequently, we conclude that this regression can be employed as reference.
\end{abstract}

KEY WORDS: Temperature Food limitation Estuarıne copepods Gutclearance rate Turbidity zone

\section{INTRODUCTION}

For several years, there has been a controversy about the relative influence of temperature and food limitation controlling secondary production of planktonic copepods (Huntley \& Boyd 1984, Huntley \& Lopez 1992, White \& Roman 1992, among others). Some authors have tried to quantify ingestion and production in order to establish carbon or nitrogen budgets (White \& Roman 1992, Irigoien \& Castel 1995), but it appears to be difficult to reach a conclusion because the ingestion of different possible food sources (phytoplankton, microzooplankton and detritus) is difficult to estimate in the field, and the gross growth efficiency (in units of carbon) appears to be quite variable, from 9 to $60 \%$ (Heinle et al. 1977, Barthel 1983, Kiørboe et al. 1985). In macrotidal estuarine systems this problem is enhanced by the fact that primary production is light limited (Cole \& Cloern 1984) by the presence of a maximum turbidity zone (MTZ) and as a consequence, phytoplankton production is sometimes not enough to

\footnotetext{
- Present address: CSIC, Institut de Ciències del Mar, Passeig Joan de Borbó s/n, E-08039 Barculona, Spain

-E-mail: j.castel@biocean.u-bordeaux.fr
}

explain copepod secondary production (Heinle \& Flemer 1975, Castel \& Feurtet 1989).

Two parameters are generally necessary for the measurement of ingestion: the gut content and the gut clearance rate (GCR) (Mackas \& Bohrer 1976). This latter parameter is controlled by temperature (Kiørboe et al. 1982 , Dam \& Peterson 1988), food concentration (Murtaugh 1985, Dagg \& Walser 1987), and food quality (Nicholajsen et al. 1983, Head \& Harris 1987). Dam \& Peterson (1988) suggested that GCR values can be obtained from a generalised GCR-temperature relationship when food conditions are not limiting.

Our objective in this work was to infer a possible food limitation in estuarine copepod species from the comparison between the GCR-temperature relationship obtanned in the laboratory with food in excess and the GCR-temperature relationship obtained in the field.

\section{MATERIALS AND METHODS}

Field work was carried out during 1992 and 1993 in the Gironde estuary of SW France $\left(45^{\circ} 22^{\prime} \mathrm{N}, 0^{\circ} 48^{\prime} \mathrm{W}\right)$, which is highly turbid. Suspended particulate matter 
(SPM) frequently exceeds $1 \mathrm{gl}^{-1}$, and as a consequence, primary production is generally low or nil in the MTZ (CNEXO 1977). It was therefore likely that food limitation situations could occur. A description of the Gironde estuary can be found in Castel (1993).

The dominant copepods in the Gironde are Eurytemora affinis and Acartia bifilosa. These 2 species are spatially separated, with $E$. affinis appearing associated with the MTZ, and $A$. bifilosa situated downstream of the MTZ (Irigoien \& Castel 1995). Maximum abundances occur in spring for $E$. affinis and in summer for A. bifilosa.

GCR experiments were carried out at 6 temperatures $\left(6,10,14,18,22\right.$ and $\left.26^{\circ} \mathrm{C}\right)$ with Eurytemora affinis and at 5 temperatures with Acartia bifilosa (because it was not possible to maintain this species at $6^{\circ} \mathrm{C}$ ). These temperatures represent the range found in the Gironde (Castel 1993). Copepods caught in the field were maintained in aquaria and adapted to the experimental temperature by steps of $2^{\circ} \mathrm{C}$ each $18 \mathrm{~h}$. During this time, they were fed Isochrysis galbana which was also used later during the experiment. For the experiment, adult copepods were placed individually in $100 \mathrm{ml}$ beakers, and I. galbana was added until a slightly green colour was obtained. A few drops of the $I$. galbana culture were added every $4 \mathrm{~h}$ to maintain a high concentration of food $\left( \pm 20 \mu \mathrm{g} \mathrm{chl} \mathrm{a} \mathrm{l}^{-1}\right)$. Faecal pellets were counted under dissection microscope and removed every $2 \mathrm{~h}$ during $1 \mathrm{~d}$ to determine possible diel variations in the feeding rhythms. Visual inspection indicated that most of the animals had 1 pellet in the gut (average: 1.1 pellet). Five replicates were performed of each experiment. GCR $\left(\mathrm{min}^{-1}\right)$ was calculated from Peterson et al. (1990) as GCR $=x / t n$ where $x$ is the number of faecal pellets produced, $t$ is the time and $n$ is the number of faecal pellets in the copepod.

In field experiments, it was impossible to employ this method because the turbidity of the water and deposition in the beakers avoided the possibility of counting faecal pellets. GCR was therefore estimated from the decrease of the gut fluorescence of ropepors placed in filtered water just after catching them (Dagg 1983). Subsamples from the filtered water were taken every 5 min during the first $30 \mathrm{~min}$ and every $10 \mathrm{~min}$ for the subsequent $30 \mathrm{~min}$. Three replicates were measured at each time step in each experiment. Gut fluorescence was measured following Mackas \& Bohrer (1976). To estimate GCR constants, it was assumed that gut clearance of starving copepods followed an exponential decay process (Christoffersen \& Jespersen 1986). The slope of the regression of the natural log of gut pigments vs time yielded the GCR $\left(\mathrm{min}^{-1}\right.$ ) (all regressions were significant at $p<0.05$ )
While employing these 2 different approaches, we were aware that the GCR obtained from counting faecal pellets can be higher than that obtained from the fluorescence decrease in filtered water (Peterson et al. 1990); however, we compared the slope of the GCRtemperature relationship and not the absolute values, and we assumed that the slopes were not affected by the method employed. Furthermore, data from Eurytemora affinis suggested that the results obtained from the 2 methods were not significantly different.

Differences in the slope and the intercept in the GCRtemperature regressions were tested by an analysis of covariance.

\section{RESULTS}

The GCR of Eurytemora affinis in the field as well as in the laboratory was related to the temperature (Fig. 1). There were no significant differences in the slope or in the intercept $(\mathrm{ANCOVA}, \mathrm{p}>0.05): \mathrm{GCR}=0.00136 \mathrm{~T}+$ $0.00729, r=0.89, p<0.05, n=6$ in the laboratory (faecal pellets method), and $\mathrm{GCR}=0.00134 T+0.00762, \mathrm{r}=0.72$, $\mathrm{p}<0.01, \mathrm{n}=14$ in the field (fluorescence method) The regression obtained for field and laboratory data together was GCR $=0.00135 T+0.0075, r=0.79, p<0.01$, $\mathrm{n}=21$.

In the laboratory, the GCR of Acartia bifilosa was positively correlated with the temperature (Fig 2), $\mathrm{GCR}=0.0015 T+0.0142, \mathrm{r}=0.97, \mathrm{p}<0.01, \mathrm{n}=5$. On the contrary, in the field the GCR of $A$. bifilosa did not show any correlation with temperature $(\mathrm{r}=-0.4, \mathrm{p}=$ $0.4, \mathrm{n}=7$ ).

Finally, we employed the data obtained by Dam \& Peterson (1988) to test the validity of a generalised

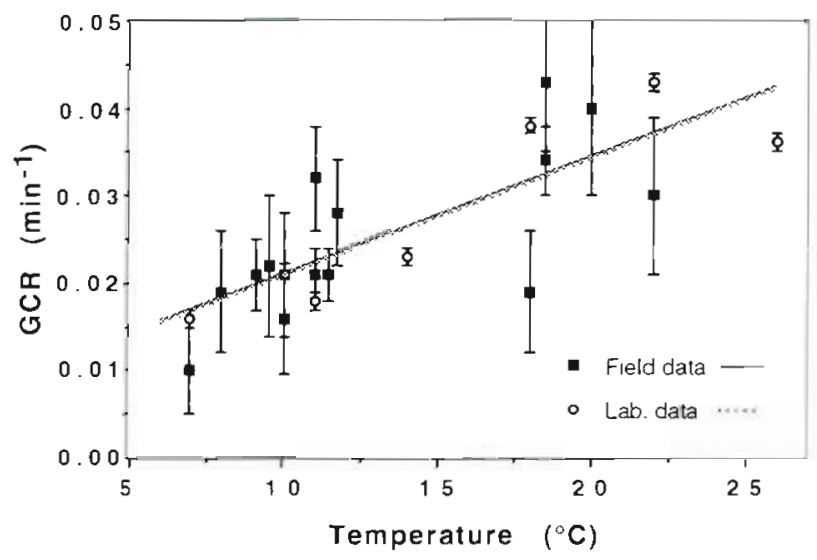

Fig. 1. Eurytemora affinis. Gut clearance rate $\left(\mathrm{min}^{-1}\right)$ as a function of temperature $\left({ }^{\circ} \mathrm{C}\right)$ in the field and in the laboratory. Vertical bars indicate the standard error of the slope (for gut fluorescence decay vs time regression) for fleld data and standard error of the mean for laboratory data 


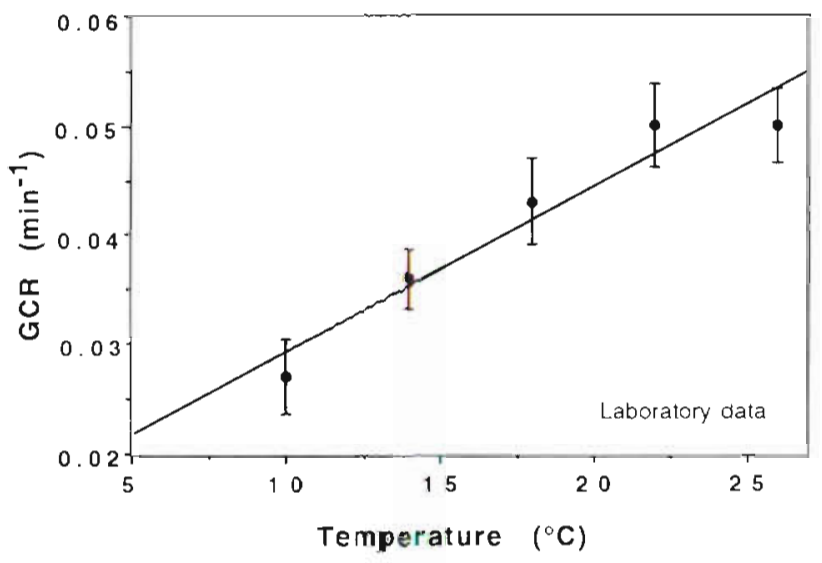

Fig. 2. Acartia bifilosa. Gut clearance rate $\left(\mathrm{min}^{-1}\right)$ as a function of temperature $\left({ }^{\circ} \mathrm{C}\right)$. Laboratory data. Vertical bars indicate the standard error of the mean

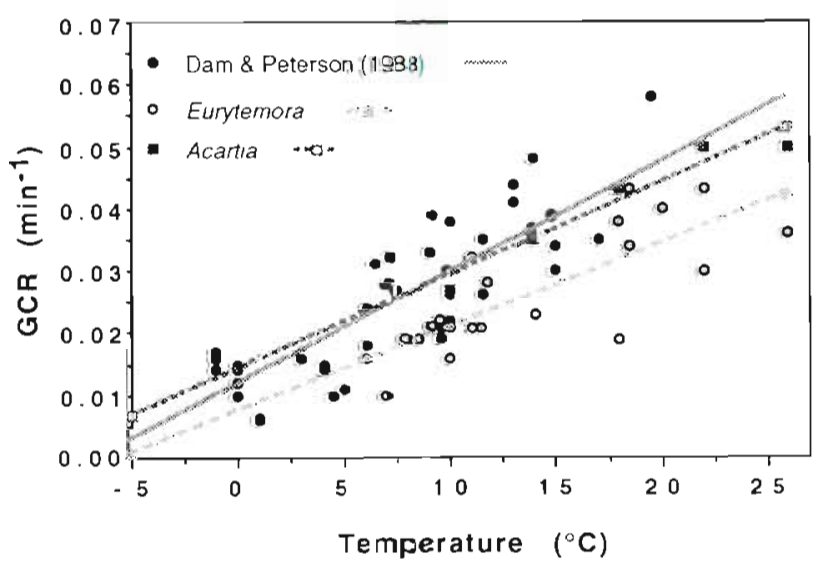

Fig. 3. Gut clearance rate $\left(\mathrm{min}^{-1}\right)$ of Acartia bifilosa (laboratory data), Eurytemora atfinis (laboratory and field data) and of data from literature (Dan \& Peterson 1988) as a function of temperature

GCR-temperature regression (Fig 3). They had measured the gut clearance rate in Temora longicornis using the gut fluorescence method both in the field and in laboratory experiments. There was no correlation between GCR and initial gut content $(r=0.40, p=0.15$, $\mathrm{n}=14$; data from their Table II). Taking their own results and data from the literature, Dam \& Peterson (1988) proposed the general relationship between GCR and temperature which is reported in our Fig 3. Slopes of the 3 regressions for Eurytemora affinis in the field and in the laboratory together, for Acartia bifilosa in the laboratory, and for the regression obtained by Dam \& Peterson (1988) did not show significant differences (ANCOVA, p >0.05). Only the intercept of the $E$. affinis regression was significantly different from the 2 others (ANCOVA, $\mathrm{p}<0.05$ ).

\section{DISCUSSION}

Our results indicate potential food limitation of Acartia bifilosa, but not Eurytemora affinis living in the Gironde estuary. The gut contents (Irigoien et al. 1993) and productivity (Irigoien \& Castel 1995) of A. bifilosa in the Gironde are mainly related to phytoplankton availability. Furthermore, the distribution of $A$. bifilosa appears to be related to the spatial and seasonal distribution of phytoplankton in the estuary (Irigoien \& Castel 1995). In contrast, the relationship between GCR and temperature for E. affinis in the field was not significantly different from the one obtained in the laboratory with food in excess. In addition, the gut contents of E. affinis in the Gironde are not related to the phytoplankton availability (Irigoien et al. 1993) and the productivity of the species is clearly controlled by temperature (Castel \& Feurtet 1989). It is likely that $A$. bifilosa is food limited whereas $E$. affinis is not. The apparent differences in food limitation between the 2 species could be due to different feeding behaviours. From Itoh's (1970) mandible edge index measurements, Castel (1981) suggested that A. bifilosa is an omnivorous species that feeds on larger particles than does $E$. affinis. Richman et al. (1977) and Bartram (1980) showed that Acartia tonsa, which is morphologically related to A. bifilosa and also present in the Gironde in late summer, feeds on larger particles than do either E. affinis or Paracalanus parvus, and Paffenhöfer (1991) concluded that $A$. tonsa is physically unable to feed efficiently on small cells. Paffenhöfer \& Stearns (1988) suggested that the distribution of $A$. tonsa is limited to nearshore environments because its efficiency in capturing particles decreases at low food concentrations. Furthermore, a number of small inorganic particles can disturb the feeding mechanisms of the copepods (Sherk et al. 1974). So, Acartia sp. could be food limited in the Gironde, where the turbidity is high, the SPM is mainly composed of clays (mean diameter: 4 to $11 \mu \mathrm{m}$, mode of the distribution: 1.5 to $2.5 \mu \mathrm{m}$; Irigoien \& Castel 1995) and the concentration of large particles is low. On the other hand, the capacity of $E$. affinis to feed on smaller particles probably allows this copepod to profit from different sources of organic carbon such as nanoplankton, organic detritus and bacteria (Berk et al. 1977, Boak \& Goulder 1983, Gyllenberg 1984).

We suggest that the comparison of the GCR-temperature relationships in the field and in laboratory conditions is a useful method to check possible food limitation situations. In the field, GCR values were estimated by the gut fluorescence method, which is usually employed to determine phytoplankton ingestion. Although both copepod species are omnivorous, this method provides valuable results since fluorescence is only considered as a tracer, assuming that evacuation 
rates of phytoplankton cells and other particles are the same. Our GCR-temperature regression slopes obtained in saturating food conditions agree with the regression obtained by Dam \& Peterson (1988). Therefore, we suggest that this slope can be employed as reference for nonlimiting food conditions in copepods. Nevertheless, more work is necessary to confirm this regression, and especially to understand if slight food limitations affect the slope of this regression. In the case of a gradual change, this relationship would be employed not only to detect food limitation situations, but also to determine the degree of the limitation.

Other methods have been used to detect food limitation. For instance, in situ egg counts permit estimation of food limitation by comparison with regressionderived maximum clutch size (Runge 1985). Measurements of egg production rates are generally quite easy to make. However, since GCR is commonly measured in the field to estimate phytoplankton ingestion, we think that our method may provide additional information by just comparing GCR values to the general equation proposed by Dam \& Peterson (1988).

In a system as spatially limited as the Gironde, 2 dominant calanoid copepods live in completely different conditions, probably due to differences in feeding behaviour. Eurytemora affinis appears to be adapted to high turbidity, and its production is temperature controlled (Castel \& Feurtet 1989) without food limitation in spite of low primary production. On the contrary. Acartia bifilosa seems to profit from the summer phytoplankton bloom seaward of the maximum turbidity zone, while being strongly food limited during the rest of the year (Irigoien \& Castel 1995). Our results suggest that precautions have to be taken when applying general models of productivity, as proposed by Huntley \& Lopez (1992), to specific ecosystems, because the response of the copepods depends not only on the food availability, but also on more complex mechanisms such as feeding behaviour.

Acknowledgements. This research was supported by the CEC MAST I programme (project 'Major Biological Processes in European Tidal Estuaries', contract 0024.C) and the CEC Environment programme (project 'Biogeochemistry of the turbidity zone in estuaries', contract PL 910 357). X.I. was funded by the Basque country government. Thanks are due to the captain and crew of the R. V. 'Côte d'Aquitaine' (CNRSINSU). Anonymous reviewers helped us to improve the manuscript.

\section{LITERATURE CITED}

Barthel KC (1983) Food uptake and growth efficiency of Eurytemora affinis (Copepoda: Calanoida). Mar Biol 74:269-274

Bartram WC (1980) Experimental development of a model for the feeding of neritic copepods on phytoplankton. J Plankton $\operatorname{Res} 3: 25-51$
Berk SG, Brownlee DC, Heinle DR, Kling HJ, Colwell RR (1977) Ciliates as food source for marine planktonic copepods. Microb Ecol 4:27-40

Boak AC, Goulder R (1983) Bacterioplankton in the diet of the calanoid copepod Eurytemora sp. in the Humber estuary. Mar Biol 73:139-149

Castel. J (1981) Aspects de l'étude écologique du plancton de l'estuaire de la Gironde. Océanis, Paris 6.535-577

Castel J (1993) Long-term distribution of zooplankton in the Gironde estuary and its relation with environmental factors. Cah Biol mar 34:145-163

Castel J, Feurtet A (1989) Dynamics of the copepod Eurytemora affinis hirundoides in the Gironde estuary: origin and fate of its production. In: Ros JD (ed) Topics in marine biology. Scient mar 53.577-584

Christoffersen $\mathrm{K}$, Jespersen AM (1986) Gut evacuation rates and ingestion rates of Eudiaptomus graciloides measured by means of the gut fluorescence method. J Plankton Res $8: 973-983$

C $\mathrm{EXO}$ (1977) Etude écologique de l'estuaire de la Gironde. Final report, CNEXO-EDF Brest, France, p 181-219

Cole BE, Cloem JE (1984) Significance of biomass and light availability to phytoplankton productivity in San Francisco Bay. Mar Ecol Prog Ser 17:15-24

Dagg MJ (1983) A method for the determination of copepod feeding rates during short time intervals. Mar Biol 75: $63-67$

Dagg MJ, Walser WE (1987) Ingestion, gut passage, and egestion by the copepod Neocalanus plumchrus in the laboratory and in the subarctic Pacific ocean. Limnol Oceanogr 32:178-188

Dam HG, Peterson WT (1988) The effect of temperature on the gut clearance rate constant of planktonic copepods. J exp mar Biol Ecol 123: 1-14

Gyllenberg G(1984) The role of bacteria in Eurytemora feeding behaviour. Crustaceana 7:229-232

Head EJH, Harris LR (1987) Copepod feeding patterns before and during a spring bloom in Bedford Basin, Nova Scotia. Mar Ecol Prog Ser 40:221-230

Heinle DR, Flemer DA (1975) Carbon requirements of a population of the estuarine copepod Eurytemora affinis. Mar Biol 31:235-247

Heinle DR, Harris RP, Ustach JF, Flemer DA (1977) Detritus as tood for estuarine copepods. Mar Biol 40:341-353

Huntley M, Boyd C (1984) Food-limited growth of marine zooplankton. Am Nat 124:455-478

Huntley ME, Lopez MDG (1992) Temperature dependent production of marine copepods: a global synthesis. Am Nat 140:201-24:2

Irigoien X, Castel J (1995) Feeding rates and productivity of the copepod Acartia bifilosa in a highly turbid estuary; the Gironde (SW France). Hydrobiologia 311:115-125

Irigoien X, Castel J, Sautour B (1993) In situ grazıng activity of planktonic copepods in the Gironde estuary. Cah Biol mar $34: 225-237$

Itoh K (1970) A consideration on feedıng habits of planktonic copepods in relation to the structure of their oral parts. Bull Plankton Soc Japan 17:1-10

Kiorboe T, Møhlenberg F. Hamburger K (1985) Bioenergetics of the planktonic copepod Acartia tonsia: relation between feeding, egg production and respiration, and composition of specific dynamic action. Mar Ecol Prog Ser 26: $85-97$

Kiorboe T, Mohlenberg F, Nicolajsen H (1982) Ingestion rate and gut clearance in the planktonic copepod Centropages hamatus (Lilljeborg) in relation to food concentration and temperature. Ophelia 21:181-194 
Mackas D, Bohrer R (1976) Fluorescence analysis of zooplankton gut contents and an investigation of diel feeding patterns. J exp mar Biol Ecol 25:77-85

Murtaugh PA (1985) The influence of food concentration and feeding rate on the gut residence time of Daphnia. J Plankton Res 7:415-420

Nicolajsen H, Møhlenberg F, Kiørboe T (1933) Algal grazing by the planktonic copepods Centropages hamatus and Pseudocalanus sp. Diurnal and seasonal varation durng the spring phytoplankton bloom in the Oresund. Ophelia 22:15-31

Paffenhofer GA (1991) Some characteristics of abundant subtropical copepods in estuarme, shelf and oceanic waters. Proceedings of the fourth international conference on copepoda. Bull Plankton Soc Japan, Spec Vol:201-216

Paffenhöfer GA, Stearns DE (1988) Why is Acartia tonsa (Copepoda: Calanoida) restricted to nearshore environment? Mar Erol Prog Ser 42:33-38

Pcterson W, Painting S, Barlow R (1990) Feeding rates of Calanordes carinatus: a comparison of five methods in-

This article was submitted to the editor cluding evaluation of the gut fluarescence method. Mar Ecol Prog Ser 63:85 -92

Richman S, Heinle DR, Huff R (1977) Grazing by adult estuarine calanoid copepods of the Chesapake Bay. Mar Biol 42:69-84

Runge JA (1985) Relationship of egg proctuction of Calanus pacificus to seasonal changes in phtotitiankton availability in Puget Sound, Washington. Limmol Oceanogr 30: $382-396$

Sherk JA, O'Connor JM, Neumann DA, Price RD, Wood KV (1974) Effects of suspended sediments on feeding activity of the copepods Eurytemora affinix and Acartia tonsa. In: Effects of suspended and deposived sediments on estuanne organisms, phase II. Find treport, chapter 8. reference nos.74-20. Natural Resourc $\geqq$ institute, University of Maryland, Prince Frederick, p 16ij-200

White JR, Roman MR (1992) Egg production of the calanoid cupepod Acartia tonsa in the mesolutine Chesapeake Bay: the importance of food resources and temperature Mar Ecol Prog Ser 86:239-249

Manuscript first received: December 19, 1944

Revised version accepted: July 26, 1995 